Original Article

\title{
Behavioral repertoire of the Brazilian spiny-rats, Trinomys setosus and Clyomys laticeps: different levels of sociality
}

\author{
Repertório comportamental dos ratos-espinhos brasileiros, Trinomys setosus e Clyomys \\ laticeps: diferentes níveis de socialidade
}

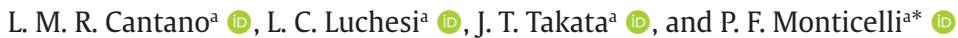 \\ aUniversidade de São Paulo - USP, Faculdade de Filosofia, Ciências e Letras de Ribeirão Preto - FFCLRP, Departamento de Psicologia, Laboratório \\ de Etologia e Bioacústica - EBAC, Programa de Pós-Graduação em Psicobiologia em Psicobiologia, Ribeirão Preto, SP, Brasil
}

\begin{abstract}
Behavior is a useful trait for comparative studies that provide the comprehension of phylogenetic relationships among species. Here, we present a description of two spiny-rats species' behavioral repertoire, Clyomys laticeps and Trinomys setosus (Rodentia: Echimyidae). The affiliative and agonistic behavioral patterns were sampled during a three-year study of captive populations of wild animals. Observational data were collected in two phases under different arrangements of individuals in groups. We also compare the behavioral traits of $T$. setosus and C. laticeps with the known behavioral patterns of Trinomys yonenagae. We add categories to the previous descriptions of T. setosus and a standard ethogram for C. laticeps. Trinomys setosus showed a visual and vocal display we called foot-trembling, which was not described in this form and function for other species studied until now. We discuss the differences in their sociality levels and similarities and differences among behavior patterns and repertoires.
\end{abstract}

Keywords: Brazilian Cerrado, seismic communication, ethogram, neotropical species, rodents.

\begin{abstract}
Resumo
O comportamento é uma característica útil para estudos comparativos que fornecem a compreensão das relações filogenéticas entre as espécies. Apresentamos aqui uma descrição do repertório comportamental de duas espécies de ratos-de-espinho Clyomys laticeps and Trinomys setosus (Rodentia: Echimyidae). Os padrões comportamentais afiliativos e agonísticos foram amostrados durante um estudo de três anos em populações de animais silvestres em cativeiro. Os dados foram coletados em duas fases sob diferentes arranjos de indivíduos em grupos sociais. Comparamos as características comportamentais de T. setosus e C. laticeps com as da espécie mais conhecida, $T$. yonenagae. Adicionamos categorias às descrições anteriores de T. setosus, e um etograma padrão para C. laticeps. Trinomys setosus mostrou uma exibição visual e vocal que chamamos de saltitar, que não foi descrito nesta forma e função para outras espécies do gênero estudado até agora. Discutimos diferenças nos níveis de socialidade e similaridades e diferenças entre os padrões comportamentais e repertórios.
\end{abstract}

Palavras-chave: Cerrado, comunicação sísmica, etograma, espécies neotropicais, roedores.

\section{Introduction}

Behavioral categorization is the obligated start point of fundamental research in Ethology (Lehner, 1996; Burkhardt, 2005). Particular behaviors allow functional hypothesis propositions about their mechanisms, developmental processes, and distal causations (Tinbergen, 1963; Ten Cate, 2009). Thus, differences among species in affiliative and aggressive displays may provide insights about signal evolution and phylogenetic relationships (Lorenz, 1966). In behavioral sciences, well-described behavioral patterns of rodents and other laboratory models (Norton and Carreño Gutiérrez, 2019) serve as operational variables for evaluating and testing treatment effects in brain disorders
(Donatti and Leite-Panissi, 2011; Cameron et al., 2018). Thus, animal welfare science has improved life quality by knowing better the socio-cognitive abilities of domestic species (e.g., Briefer et al., 2015) and investigating molecular mechanisms related to the evolution of behavioral complexity and sophistication (Grant, 2016).

Despite their importance, most of the Neotropical species repertoires were not described. Field observation's practical difficulties may account for this lack, especially when considering that most species are tame or have nocturnal habits (Dorph and McDonald, 2017). Most of what is known about mammal's behavior from a comparative perspective came from populations of free-living animals

*e-mail: laiscantano@gmail.com

Received: July 20, 2020 - Accepted: March 02, 2021

This is an Open Access article distributed under the terms of the Creative Commons Attribution License, which permits unrestricted use, distribution, and reproduction in any medium, provided the original work is properly cited. 
captured in the wild (or rescued) and established in animal facilities in universities or zoos (Kleiman, 1974; Kleiman et al., 1979; Dorph and McDonald, 2017).

Trinomys setosus Desmarest (1817) and Clyomys laticeps are part of sister taxons of Echimyidae rodents restricted to South America (Galewski et al., 2005). The taxon Clyomys+Euryzygomatomys and Trinomys may have evolved in eastern Brazil (Fabre et al., 2013; 2016). The genus Trinomys got widely distributed, and $T$. setosus is the broadest geographic range species (Pessôa et al., 2015), restricted to forest habitats. It feeds on fruits and opportunistically on insects and seeds (Fonseca and Kierulff, 1989). Clyomys laticeps got restricted to the Cerrado today (Bezerra and Oliveira, 2010), living on grassland open areas and their underground (Thomas, 1916; Bishop, 1974). This species excavates burrow systems in the sandy soil and stays there during the light phase, probably as shelter from predators and to the extreme climatic stressful fluctuations (Ferrando and Leiner, 2018), and may use the underground as a safe route among foraging areas (Luchesi, 2019).

There is sparse information about T. setosus and C. laticeps social (Freitas et al., 2008) and acoustic life (Takata et al., 2014). On the other hand, T. yonenagae is a well-known species concerning its taxonomy, physiology, and behavior (Luchesi et al., 2019). It diverged from a common ancestral relationship with $T$. setosus about 8.5 million years ago in the late Miocene (Tavares et al., 2015). Manaf and Spinelli Oliveira (2000) offered the first description of its behavioral repertoire. It included social patterns as intra and inter-sexual allogrooming and naso-anal contact, nasoauricular contact followed by heaping, and a naso-nasal display performed by individuals standing side by side in full-body touch after approaching. Agonistic behaviors (i.e., those that increase the distance between animals or that promote/avoid physical injuries; Freitas et al., 2008) were chase, fighting, and attack that occurred shortly after individuals' first presentation, and disappeared after changing group composition; Manaf and Spinelli Oliveira (2000). In experimental paradigms (intrasexual pairing), the behavior of Trinomys setosus was compared to existing repertoires of T. yonenagae (Rocha, 1995) and resulted in hypotheses about evolutionary adaptations to a xeric environment (the Brazilian Caatinga) in T. yonenagae (Freitas et al., 2008; 2010). Not much information was added to T. setosus socioecology and behavior.

The present study aimed to analyze the social behavior repertories of Trinomys setosus and Clyomys laticeps describing their behavioral biology in distinct social contexts in captivity. We used the previous $T$. yonenagae (Manaf and Spinelli Oliveira, 2000) and $T$. setosus (Freitas et al., 2008) ethograms to provide a comparative view.

\section{Material and Methods}

\subsection{Subjects}

Animals were collected in 2010/2011 under Instituto Brasileiro do Meio Ambiente (IBAMA) license $n^{\circ} 21034-3$, and ethical approval (USP/Psychology Institute CEUA $\left.\mathrm{n}^{\circ} 5845290415\right)$. Trinomys setosus $(\mathrm{n}=19 ; 250 \pm 34 \mathrm{~g})$ came from a fragment of Atlantic Forest in the municipality of Jaguaripe, State of Bahia $\left(13^{\circ} 00^{\prime} \mathrm{S}, 38^{\circ} 01^{\prime} \mathrm{W}\right)$, Bahia state, Brazil. Clyomys laticeps $(\mathrm{n}=12 ; 338 \pm 34 \mathrm{~g})$ were collected in Cerrado open areas in the Itirapina Ecological Station

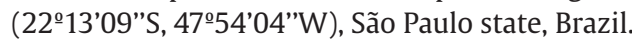

Individuals were housed together in pairs or groups in the Ecophysiology and Behavior Lab (LECO) and Ethology and Bioacoustics Lab (EBAC) husbandry facilities for two years. In both facilities, controlled conditions systems kept animals isolated from external interference (air renewal: every $60 \mathrm{~min}$, temperature-controlled $24.0 \pm 2.0^{\circ} \mathrm{C}$, and 12:12 light/dark cycle). We decided to adopt the light/dark circle reversed, regarding the species basal metabolic rate dynamic (Fabio-Braga and Klein, 2018) and following $T$. yonenagae's activity pattern in captivity (Marcomini and Oliveira, 2003).

Trinomys setosus and C. laticeps were later grouped in enclosures $(80 \times 95 \mathrm{~cm})$. The ground was lined with wood shavings and bed and shelter materials, such as hay or alfalfa, rollers, tubes, and cardboard boxes to enrich the enclosure environment. Water and food were offered ad libitum, and once a week, their diet was supplemented with fresh edible items, and they were weighted. After three months of observing Clyomys, we lost access to the LECO facility where they were and had to conclude the study with this species.

\subsubsection{Grouping and behavior recordings}

Behavioral observations of $T$. setosus (Table 1 ) were carried out in two phases, and $C$. laticeps just in one. In Phase 1, participated only $T$. setosus species and data were collected in three situations: a) 30min pairing sessions of male and female in their first presentation to each other; b) 37 records of instantaneous verification of proximity among individuals in the resting time (light phase, once a day); c) 5 sessions of 30 min individual focal sampling under group condition. In Phase 2, participated both Trinomys and Clyomys species and data were collected in two situations: d) 66 records of instantaneous verification of proximity among Trinomys setosus individuals and 45 registers of proximity among individuals during the resting period (light phase, once a day) for Clyomys individuals (CG2 group); and e) 60min-sessions of group recording without human interference, summing up $93 \mathrm{~h}$ for $T$. setosus and $71 \mathrm{~h}$ for $C$. laticeps.

\subsubsection{Phase 1}

Initially, four individuals of Trinomys setosus (two females named Meg and Tina, and two males, Johnny and Tom) were reunited in two pairs: Meg+Johnny (TP1) and Tina+Tom (TP2). The couples were observed in independent sessions. Then, two 4-animals' groups were formed, one by the reunion of Meg+Johnny (TP1) with Tina+Tom (TP2), named Trinomys group 1 (TG1, Table 1); and the other by the reunion of Peter, Zac, Fanny and Amy (named TG2-0; Table 1). The distance among animals during the light phase, when they were resting, was registered in 37 days. We were interested in patterns that could suggest social preference of affinity. 
Table 1. Trinomys setosus and Clyomys bishopi group composition. Individuals are cited by the name we adopted and their sex indicated by symbols. The last column shows the time window when observation and sampling behavior occurred (months of year) and the total number of hours sampled to the behavioral analysis. TG are T. setosus groups and CG are C. bishopi groups. The data of first four groups were collected by JTT, and the last ones by LMRC.

\begin{tabular}{|c|c|c|}
\hline Group & Individuals & Period observed/hours \\
\hline \multicolumn{3}{|c|}{ Trinomys setosus } \\
\hline TG1-0 & $\uparrow$ Meg $\uparrow$ Tina $\lesssim$ Johnny $\precsim$ Tom & March 2014/10h \\
\hline TG2-0 & $\Varangle$ Amy $\rho$ Fanny $\precsim$ Peter $\precsim$ Zac & May 2014/10h \\
\hline TG1-1 & $\begin{array}{c}q \text { Meg } q \text { Tina } q \text { Lola } q \text { Bela } \hat{\jmath} \text { Johnny } \hat{\jmath} \\
\text { Zac } \lesssim \text { Charlie }\end{array}$ & 2015 January to May / 44h \\
\hline TG1-2 & 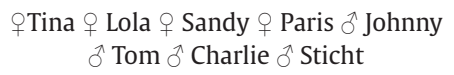 & $\begin{array}{l}2016 \text { February to April and } 2016 \text { June } \\
\qquad / 27 \mathrm{~h}\end{array}$ \\
\hline TG2-1 & 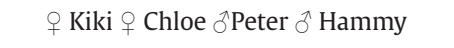 & 2015 March to April / 22h \\
\hline \multicolumn{3}{|c|}{ Clyomys bishopi } \\
\hline CG1 & q $\mathrm{F} 2 \lesssim \mathrm{M} 2$ & $\begin{array}{c}2014 \text { October, } 2015 \text { January, July and } \\
\text { August / 20h }\end{array}$ \\
\hline CG2 & 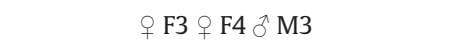 & 2014 October and 2015 January $/ 11 \mathrm{~h}$ \\
\hline CG3 & $q \mathrm{~F} 4$ f F7 $q \mathrm{~F} 8$ & 2015 July and August / 19h \\
\hline CG4 & q F3 $q$ F5 $q$ F6 $\bigcirc$ M3 & 2015 July and August / 21h \\
\hline
\end{tabular}

Behavior sampling for repertoire description consisted of five sessions, one of group formation (TG2-0); two after altering groups composition by the exchange of males Tom and Zac from their original group (TG1-0 and TG2-0'); and two sunflower seeds delivery (TG1-0; TG2-0 one each). All situations were recorded in the dark phase, except in sunflower seeds delivery, during the light phase.

\subsubsection{Phase 2}

Trinomys setosus TG1-1 was observed in two conditions: first, with seven individuals, three of them infants (TG1 at the moment 1: TG1-1, Table 2) for five months; and then, with eight individuals (two new infants) TG1-2; moment 2: for another four months. Altogether, 19 individuals (four females, six males, and nine pups) were part of TG1-1 and 2, not simultaneously. Hammy and Peter (males) and Kiki and Chloe (females) formed Trinomys group 3 (TG3, Table 2) observed for two months.

Four groups of Clyomys laticeps (CG1, CG2, CG3, and CG4; Table 1) were established by reuniting individuals that were kept housed individually since their capture. A pair of individuals (F2 and M2) formed CG1 and were observed for four months (Table1). Two females and one male (F3, F4, and M3) started the group (CG2; Table 1) observed for three months. Two other groups were observed for two months: CG3 (three females: F4, F7, and F8; Table 1) and CG4 (three females and one male: F3, F5, F6, and M3; Table 1). For both species, all observations occurred in the dark phase.

\subsubsection{Session Recordings}

During Phase 1, Trinomys setosus pairing sessions (TP1; TP2) and groups at the moment 0 were quantified using a 30min continuous focal sampling method. In Phase 2, T. setosus groups at moment 1 and 2 (TG1-1; TG3 and
TG3) and Clyomys laticeps groups (CG1; CG2; CG3; CG4) were registered in $60 \mathrm{~min}$ observation sessions three times a week. The sound was registered with a Shotgun directional microphone, and the video was recorded with an infrared light system used for all situations and species during the dark phase sessions. Summing up together, the total observation time for Trinomys was $140.18 \mathrm{~h}$ and 71h for Clyomys.

\subsection{Design (Strategy)}

\subsubsection{Behavior identification and quantification}

For Phase 1, we measured time spent in each behavioral category (duration): Maintenance and Locomotion/ Exploratory behaviors (locomotion, alert posture, drinking, eating/foraging, digging, grooming, rearing) and Reproductive behavior (mounting) provided by Manaf and Spinelli Oliveira (2000) together in a compacted version (see results section) of the T. setosus ethogram provided by Freitas et al. (2008), that encompasses six other behavioral studies of Trinomys, with a few modifications. Additionally, we used the category no movement to rest alone and staying alone postures. We sampled behavioral categories (affiliative, agonistic, or reproductive) in Phase 2, using all occurrence sampling methods (Altmann, 1974).

In Phase 1, we analyzed time spent and relative frequency of every considered behavior, grouping them into five functional categories: agonistic, affiliative, resting maintenance+locomotion (includes bury), and mount (the only in reproductive category) behaviors. We also estimated the proportion of time spent in these two behavioral categories by the mean time duration of behaviors. We analyzed the number of manipulated seeds during seed delivery for each individual, noting if they eat or buried them. In Phase 2, instead of considering time spent in each 
Table 2. Date of birth of Trinomys setosus in captivity (all them mothered by Meg, except Hammy, mothered by Fanny). For those captured in the wild, this information is unknown. TG1 and TG2 are T. setosus groups. LECO: Ecophysiology and Behavior Lab.

\begin{tabular}{|c|c|c|c|}
\hline Group & Sex/ID & Day of birth & Destination \\
\hline \multirow[t]{5}{*}{ TG1-1 } & q Lola & 10- October-2014 & $\begin{array}{l}\text { maintained in the laboratory } \\
\text { and transferred to LECO (July } \\
\text { 2016) }\end{array}$ \\
\hline & ônarlie & 10- October-2014 & $\begin{array}{l}\text { maintained in the laboratory } \\
\text { and transferred to LECO (July } \\
\text { 2016) }\end{array}$ \\
\hline & q Bela & 23-January-2015 & $\begin{array}{c}\text { transferred to another } \\
\text { laboratory (LECO; May 2015) }\end{array}$ \\
\hline & q Linda & 23-January-2015 & died in February 2015 \\
\hline & Charlie & 10- October-2014 & maintained in the laboratory \\
\hline \multirow[t]{5}{*}{ TG1-2 } & q Lola & 10- October-2014 & $\begin{array}{l}\text { maintained in the laboratory } \\
\text { and transferred to LECO (July } \\
\text { 2016) }\end{array}$ \\
\hline & q Sandy & 20-July-2015 & $\begin{array}{l}\text { maintained in the laboratory } \\
\text { and transferred to LECO (July } \\
\text { 2016) }\end{array}$ \\
\hline & $q$ Paris & 20-July-2015 & died in August 2016 \\
\hline & q Lilo & 22-April-2015 & $\begin{array}{c}\text { transferred to another } \\
\text { laboratory (LECO; November } \\
\text { 2015) }\end{array}$ \\
\hline & $\widehat{o}$ Sticht & 22-April-2015 & $\begin{array}{l}\text { maintained in the laboratory } \\
\text { and transferred to LECO (July } \\
\text { 2016) }\end{array}$ \\
\hline TG2-1 & ô Hammy & 02-September-2014 & $\begin{array}{l}\text { maintained in the laboratory } \\
\text { and transferred to LECO (July } \\
\text { 2016) }\end{array}$ \\
\hline
\end{tabular}

behavioral category, we analyzed the number of times the emitter (the individual who initiated) and the recipient (receiver) of the behavior. For both phases, we counted the proximity of individuals during the resting period (light phase), during three (Phase 1), and five months (Phase 2). In Phase 2, we collected no data from TG1-2 that was no longer with us. We identified the animals resting in physical contact, considering an inter-individual distance up to "a body length".

\section{Results}

\subsection{Behavioral patterns}

We identified 20 behavioral categories (Table 3 and 4 ) in Trinomys setosus and Clyomys laticeps. We grouped similar behaviors: bite-the-lumbar, bite-the-rostrum, and bite-the-tail in bite; grab-from-ahead and grab-from-behind in grab; hit-the-lumbar and hit-rostrum in hit; runaway and turn-away-vigorously were grouped in run away; stop-in-contact and stay underneath were grouped in stop in contact. Thus, face the other included the biped posture variation; and nasal or rostrum contacts were grouped according to the body region touched: anal, auricular and nasal/rostral, lumbar. Tables 3 and 4 show the behaviors (affiliative and agonistic) exhibited by Trinomys setosus and Clyomys laticeps. Results are presented below first by species and then in a comparison between them.

\subsection{Trinomys setosus repertoire}

\subsubsection{Proportions of affiliative and agonistic behaviors}

In Phase 1, in the five observational situations (two group reunions and three seed delivery), we registered 2,150 behavioral occurrences. Among them, 22.5\% (483) were composed of affiliative behaviors. The allogrooming was recorded 48 times (10\%), mostly by females (69\% of them). In 13 times, allogrooming was directed from Fanny to Tom when he was new in the group. Other occurrences of affiliative behaviors (77.5\%) included approach (55 times), stop in contact (116 times), all five naso/rostrum contacts categories (244 times), touch with forefeet (21 times). The mounting behavior was observed eight times, which corresponds to $1.65 \%$ of the affiliative behaviors. All of them occurred in TG2 at the group formation. Peter mounted the new male (Zac), and the pelvic movements were noticed. The agonistic behaviors corresponded to only $5.1 \%$ of all occurrences and were face-the-other (2 times), hit (6 times), attack (42 times), and run away (56 times). No kick behavior occurred.

Locomotion/exploratory behaviors were registered in $44.4 \%$ of the 2,150 behavioral occurrences in the five sessions. The digging behavior corresponded to only $1.5 \%$ 
Table 3. The non-aggressive behavioral patterns shown by individuals of our sample of Trinomys setosus and Clyomys bishopi. Behaviors are named following Freitas et al. (2008).

\begin{tabular}{llll}
\hline Affiliative & Description & T. setosus & C. bishopi
\end{tabular}

\section{Allogrooming}

Approach

Stop in contact (includes "Place head on the other")

Naso-anal contact (includes rostrum contact)

Naso-auricular contact

Naso-tail contact (includes rostrum contact)

Naso-nasal contact (includes rostrum-rostrum contact)

Naso-lumbar contact (includes rostrum contact)

Touch with forefeet

Mount

Foot-trembling display
To comb another animal

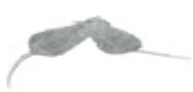

To approach another animal

To lay down or sit in contact. Usually, one animal smells the other before stopping in contact. Animals may lie the head on the others body

To touch or sniff the anal region of others

To touch with the muzzle the ear of others with vigorous movements
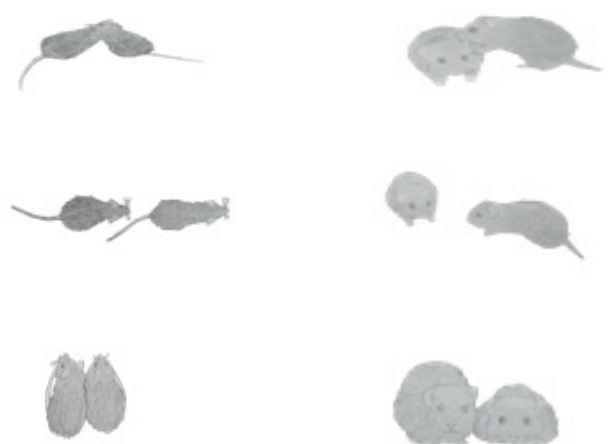

To approach, smell or touch on the tail of others

To touch the nasal region of others

To touch the lumbar region of others with the muzzle, mouth or other region of the face

To touch the head or chest of another animal with the front paws

To approach the partner by placing the front paws on the back, whether or not followed by pelvic movements
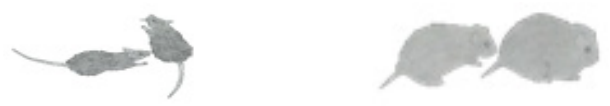

Not observed
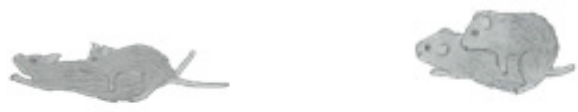

Not observed
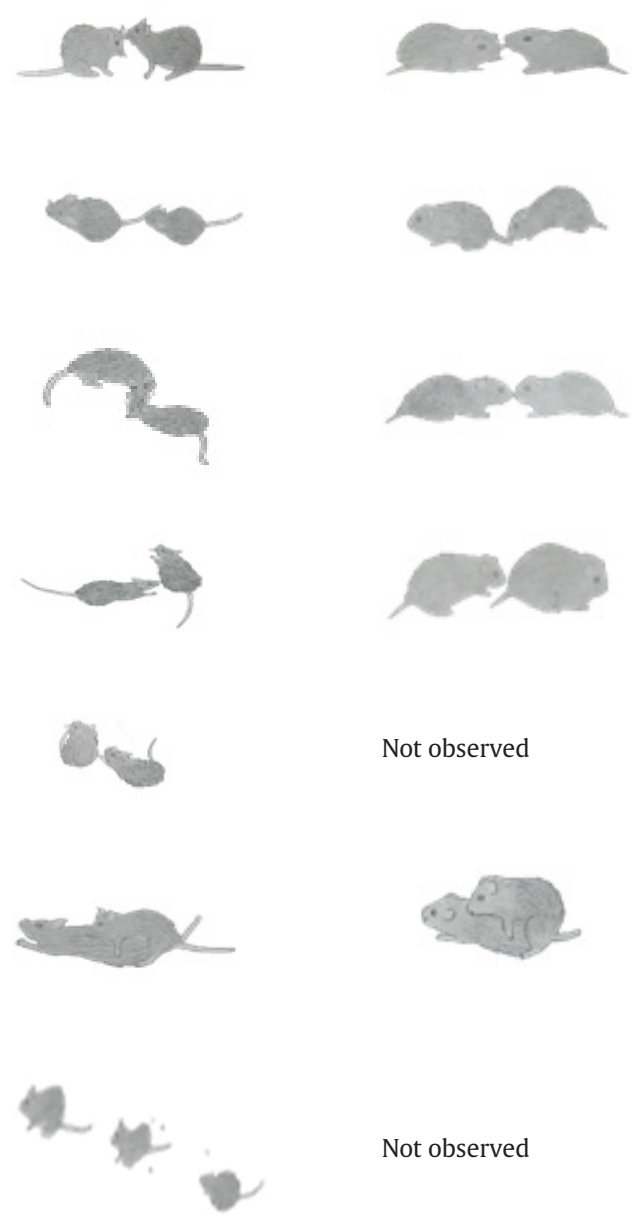

To tap the soil in rapid movements of the hind legs, moving up and down the posterior region of the body. Accompanied by trilled whine (Figure 1) 
Table 4. The aggressive behavioral patterns shown by individuals of our sample of Trinomys setosus and Clyomys bishopi. Behaviors are named following Freitas et al. (2008).

\begin{tabular}{|c|c|c|c|}
\hline Agonistics & Description & T. setosus & C. bishopi \\
\hline Advance & $\begin{array}{l}\text { To move fast toward another } \\
\text { animal without physical } \\
\text { contact }\end{array}$ & & \\
\hline Attack & $\begin{array}{l}\text { To approach abruptly from } \\
\text { another animal, and may or } \\
\text { may not bite it }\end{array}$ & & \\
\hline Bite & $\begin{array}{l}\text { To bite another animal and } \\
\text { eventually causing it to flee }\end{array}$ & & \\
\hline Chase & $\begin{array}{l}\text { To follow another animal at } \\
\text { high speed }\end{array}$ & & \\
\hline Face the other & $\begin{array}{l}\text { To approach the face of } \\
\text { another animal slowly, } \\
\text { stopping at a distance } \\
\text { smaller than a body }\end{array}$ & & \\
\hline Grab from behind & $\begin{array}{l}\text { To grab another animal with } \\
\text { its front legs, remaining in } \\
\text { that position for a moment } \\
\text { or pushing }\end{array}$ & & \\
\hline Hit & $\begin{array}{l}\text { To hit on the lombar region } \\
\text { or on the head of another } \\
\text { animal with one or two front } \\
\text { paws }\end{array}$ & & \\
\hline $\begin{array}{l}\text { Run away (turn away } \\
\text { vigorously) }\end{array}$ & $\begin{array}{l}\text { To move in the opposite } \\
\text { direction of an animal that } \\
\text { chases it }\end{array}$ & & \\
\hline
\end{tabular}

Drawings are based on video and still images taken from animals during the recording by J. Takata (Takata et al., 2014).

of all behavioral occurrences (33 times). T. setosus did not excavate burrows: it would pick up the food (seeds) and eat immediately or open a hole in the substrate (in our case, sawdust) and push the food in, with the snout (see video at supplementary materials; S3). Finally, the maintenance behaviors (eating/foraging; drinking and grooming) represented $11.4 \%$, the reproductive was $0.4 \%$, and resting was $16.3 \%$ of the behavioral occurrences.

In Phase 2, from 67 to $95 \%$ of each group, total occurrences consisted of affiliative behaviors, especially in TG3 (TG1-1: 74\%; TG1-2: 67\%; TG3: 95\%). It included the naso-anal contact displayed in intra and intersexual interactions and initiated both by males and females (so, it was not restricted to sexual interactions). Allogrooming, approach, and naso-nasal contact were the most frequent affiliative behaviors. The naso-anal contact rarely occurred (from 0.5 to $2.6 \%$ of all affiliative behaviors). Those individuals that allogroomed more were once again the females, Meg (TG1-1: 65 times), Paris (TG1-2: 18 times), and Kiki (TG3: 60 times).

A much smaller proportion of behavioral occurrences consisted of aggressive behaviors (TG1-1: 26\%; TG1-2: 33\%; TG3: 5\%). The most frequent patterns were advance, attack, and chase. In TG1, Johnny directed the touch with forefeet to Meg only four times (2\%). The other 30 occurrences were initiated by Tom, Paris, or Lola and directed to Tom, Tina, Sticht, Johnny, or Charlie. In TG3, Hammy touched all others at least once with the forefeet ( $\mathrm{n}=8$ times).

\subsubsection{Time spent in affiliative and agonistic behaviors}

Concerning the relative duration of the behavioral occurrences, in Phase 1, the proportion of time estimated by the mean duration of behaviors in the five situations are presented in Figure 2. The animals spent more time in maintenance+locomotion and affiliative behaviors 


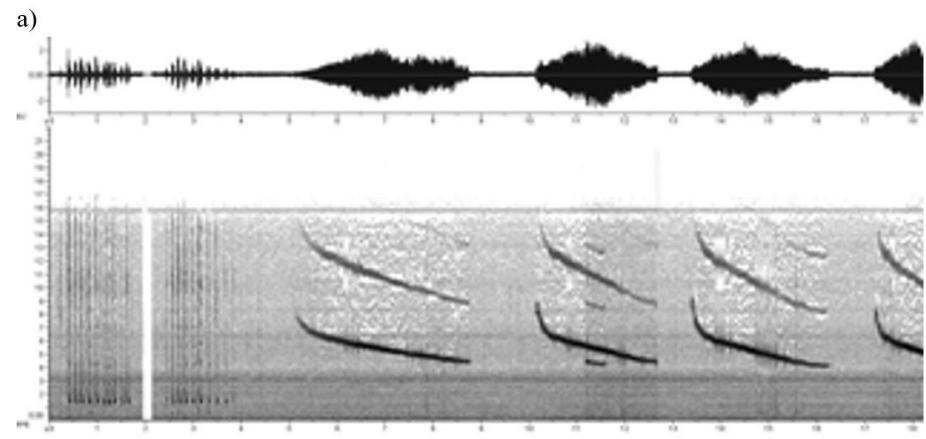

b)

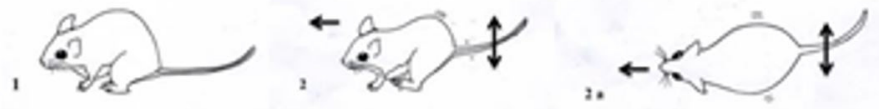

Figure 1. a) Spectrogram (bellow) and Oscillogram of the trilled whine uttered during the foot-trembling display. From 0 to 4 seconds, two independent trilled whine syllables uttered by Trinomys setosus- Johnny, after Tina entrance in an empty pairing cage test. After and during Johnny's whine, Tina uttered sequences of long whistle (from $5 \mathrm{~s}$ to the end), commonly heard by us whenever one entered the husbandry facilities. The sound was captured from video recordings and saved on a 16 bits wav file, sampled at $44 \mathrm{kHz}$. Spectrogram settings are 0,0134 s Hann window, 88\% overlap, 0,0016s hopsize and $21.5 \mathrm{~Hz}$ of grid spacing, in Raven Pró 1.5.0. b) Drawing of foottrembling behavior in T. setosus by J. Takata (Takata et al., 2014). I.initial posture, II. foot-trembling while calling, III. an animal performing movement in dorsal view. Arrows indicate the direction of movement.
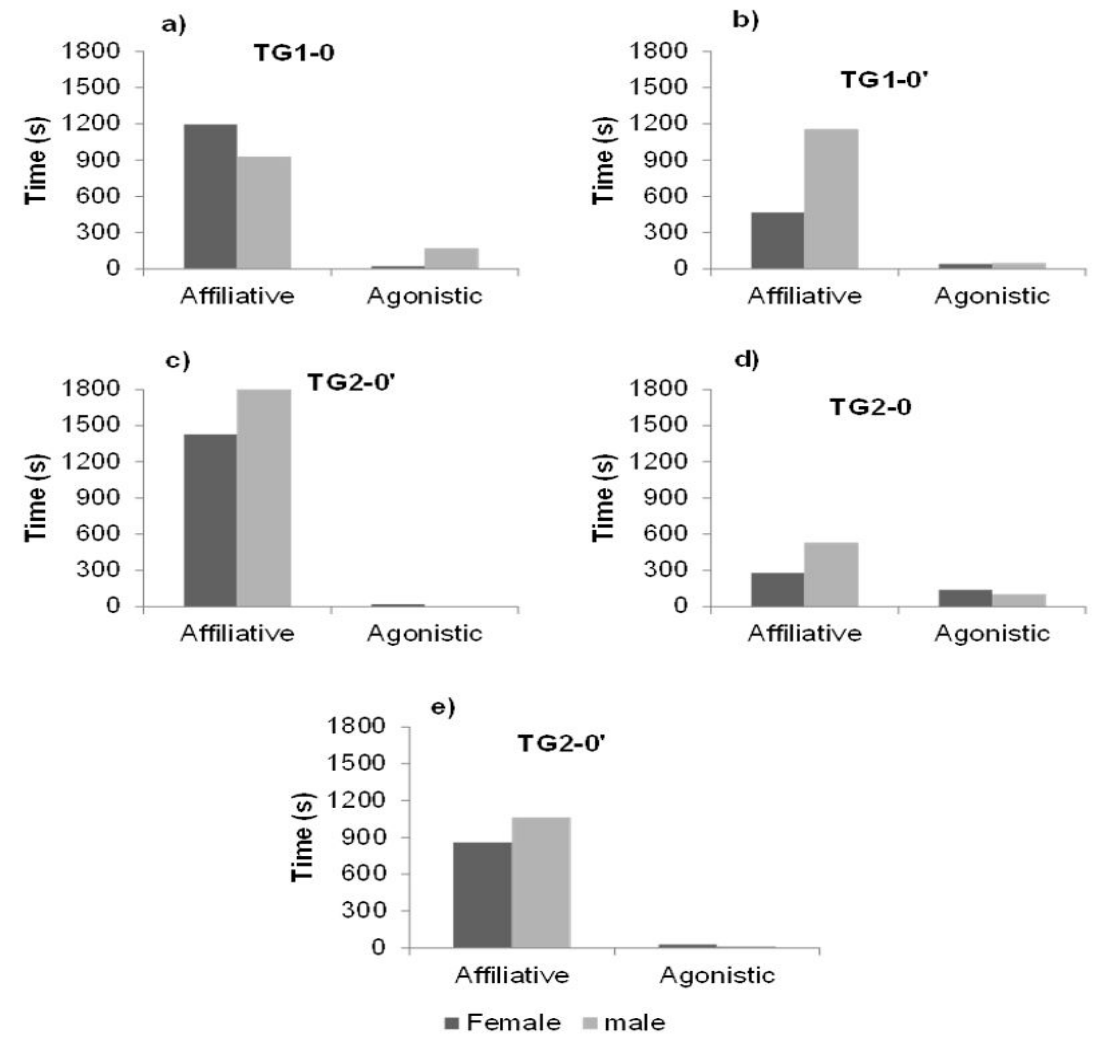

Figure 2. Time spent (in seconds) in affiliative and agonistic behaviors by the females and males of $T$. setosus groups, after seed delivery (a, b, c) and group formation (d, e) in $30 \mathrm{~min}(1,800 \mathrm{~s})$ experimental sections under continuous focal strategy. Groups were formed by 4 individuals (2 males and 2 females), TG1-0 (Meg, Tina, Johnny, Tom); TG1-0' (Meg, Tina, Johnny, Zac); TG2-0 (Amy, Fanny, Peter, Zac) and TG2-0' (Amy, Fanny, Peter, Tom). 
than in resting, agonistic, or mounting, except after reunions (Figure 2c); TG2-0' exhibited as many affiliative (816.8 $\pm 228.8 \mathrm{~s})$ than maintenance behaviors (790.6 $\pm 262.6 \mathrm{~s})$. The affiliative behavior lasts longer than the agonistics, even in seed delivery observations, for TG2- 0'. Since the reunion of animals in TG2-0', they spent more time in affiliative (reunion: $959.8 \pm 145.5 s$; seed delivery: 1,633.6 $\pm 290.5 s$ ) than in agonistic behaviors (reunion: $20 \pm 11.7 \mathrm{~s}$; seed delivery:9.3 $\pm 13.2 \mathrm{~s}$ ). In four out of 5 observational sessions, males spent more time in affiliative interactions than females. One exception was during the seed delivery of TG1-0 (Figure 2a), when females spent $13 \%$ more time in affiliative behaviors than males. Time spent in allogrooming was longer in females (almost $1 / 3$ of this time was Fanny interacting with Tom when he just arrived).

During seed delivering sessions, the focal female Meg was the one who recovered more seeds (23 seeds, all eaten) in TG1-0, followed by Johnny (17 seeds, two eaten and 15 buried) inTG1- $0^{\prime}$, and Fanny in TG2- $0^{\circ}$ (12 seeds, ten eaten and two buried).

\subsubsection{Proximity in resting}

In the resting period, in all the 36 out of the 37 total registries taken in Phase 1, there were at least one pair of individuals huddling (i.e., sleeping in physical contact with others). In 14 (37.84\%), all the animals were in the same huddling interaction. In the other $62.15 \%$ of the registries, there were triads or pairs of animals huddling. Only once we registered no animals sleeping in contact, and this was in TG2-0. Meg was the one that slept alone more times (in 12 of 37 times) in TG1-0, and it was Peter in TG2-0 ( 4 out of 5 times).

In Phase 2, we collected 66 registries of the resting patterns during the light phase. All T. setosus groups had at least one pair resting in contact in the observations; in TG1-1, Johnny and Tina were observed together in 34\% of the observations; in TG3, Peter and Hammy were seen huddling in $50 \%$ of the registries. In none of our registries, someone rested alone in this phase.

\subsubsection{Particular behaviors of the species}

The animals used to escape from their group's enclosures, somehow jumping or escalating the 1 meter wood wall. From what we saw, Tom (adult male) ran out three times in 5 months, but just once after being relocated to TG2-0. TG1-0 and TG2-0 stayed calmer after Tom being exchanged with Zac. In TG1-1, male Charlie (three months older) was found in the neighbor group 12 times, with Tom and Amy. His sister, Lola, escaped four times.

We found no ritualized courtship behavior in Trinomys setosus. Mating occurred just once during our observations in Meg's postpartum period. In this mating episode, the male Johnny was seen mounting on Meg several times. In other episodes, Johnny mounted at least once all his group individuals, including the adult male. Tina gave birth after the removal of Meg from the husbandry room.

T. setosus foot-drums, but not exactly as T. yonenagae. This behavior was composed of vocal and visual simultaneous components by apparently mildly disturbed animals: it would hit the substrate with one hindfoot in rapid movements while vocalizing a fast trilled sound. A variation of this display was registered during the Tina and Johnny reunion (Phase 1 ) in a pairing session (see video at the Supplementary materials; S1). Here, instead of standing still while drumming a hindfoot on the substrate, the female moved while drumming with one or other hind feet, producing a trembling locomotion and uttering the same call (Figure 1, Table 3). This behavior has been observed after Johnny was put where Tina was. After his introduction in the cage, she remained immobile in an alert position for a few seconds, then the male moved and stopped facing the female and that was when she trembled while trilling. They moved a lot; the male reared repeated times in the cage corners while she exhibited an interspersed movement while trembling for at least 8 minutes. A long and descendant whistle (the alarm whistle of the species) associated with human disturbance was also heard repeatedly (it was impossible to identify who was uttering it).

Thus, a foot-drumming with only one paw hitting the substrate at a fast rate was also displayed by Zac male (in TG2-0) after seed delivery to the group. Zac foot-drummed again in Phase 2, during the weekly fence cleaning (once out of four times, it happened after human noise outside the room), and while the experimenter prepared the recording equipment in the room. The other animals stood still for a few moments (see video at the supplemental materials; S2). Zac also foot-drum inside an apparatus used to weigh the animals (a plastic cage where animals stood inside).

\subsection{Clyomys laticeps}

We could observe the $C$. laticeps individuals of LECO only in the group condition, from two to four 4 months and in phase 2. Its repertoire was described based on $71 \mathrm{~h}$ of observation of four groups of 3 different compositions: 2 females and a male (CG2 and CG4), a couple, and a female group (CG1, CG2, CG3, and CG4). Behaviors had almost the same topology as those of Trinomys (Tables 3 and 4). Exceptions were the absence of foot-trembling and the touch with forefeet.

\subsubsection{Proportions of affiliative and agonistic behaviors}

Affiliative and agonistic behaviors occurred at almost the same frequency in general. Looking at the groups singularly, the CG4 presented twice affiliative than agonistic behaviors (Table 3 and 4). According to the group, the proportion of affiliative behaviors varied between 47 and 67\% (CG1: 51\%; CG2: 47\%; CG3: 55\%; CG4: $67 \%$ ); from 33 to 53\% were agonistic categories (CG1: 49\%; CG2: 53\%; CG3: 45\%; CG4: 33\%). One group conformation (CG2: F3, F4 e M3) was more aggressive, and the agonistic proportion overpassed the affiliations (53\%; affiliative 47\%). In this group, the male M3 was the one that most hit others, and F3 the one that most received. $\mathrm{F} 4$ was the most attacked by $\mathrm{F} 3$, who was also the one that most chased others. M3 also bit more frequently than the females and grabbed F4 twice. F3 was the one that most approached others, especially M3. F4 displayed most of the agonistic behaviors but did it at the same frequency as she displayed affiliative behaviors; F3 emitted more agonistic than affiliative behaviors. F4 was removed from this group, and two females were added, as described in the methods. CG4 (F3, F5, F6, and M3) turned out to be the most pacific group (affiliative behaviors overpassed the agonistics: 133 and 66 occurrences, respectively). F5 was the one that emitted the most affiliate and agonistic behaviors, and the male M3 was the one that received the most of both types. The female 
F3, contrary to when she was in CG3, rarely participated in agonistic behaviors and displayed more affiliates than received them from the others. F6 emitted more agonistic behavior than received and received more affiliative behavior than emitted. F5 approached others more, and mostly the M3. Concerning naso-nasal contact, F5 was the one that performed more, and F6 the most receptor of this behavior.

Body contact, naso-lumbar contact, naso-corporal contact, naso-caudal contact, naso auricular contact, and allogrooming occurred at low frequencies. Naso-anal contact was more often displayed by F5 and more received by F6 and the male. The female F5 was the one that chased and attacked the most, and the male and female F6 were the ones that received the most. For both affiliate and agonistic behaviors, the female F5 was the one that emitted the most, and the male M3, the one that received these types of behaviors the most.

\subsubsection{Proximity in resting}

We collected 45 registers of proximity among individuals during the resting period, all in CG2. In 4 of 13 observations
(30\%), M3 was huddling with F4 in, and the female F3 was always seen alone. Allogrooming was rarely exhibited: once in CG2 (from F4 to M3), four times from F6 and F3 to M3, and one from F5 in CG4. We recorded nine mounts (always from a male on a female and in copula position, pelvic movements seen), four in CG1 (to F2), and five times in CG2 (to F4).

\subsubsection{Particular behaviors of the species}

These animals also escaped from their group's enclosures, although we have not seen them escalating or jumping. F3 and F4 (CG2) escaped 8 and 10 times, respectively; in CG4, F6 and the male were those that most escaped (31 times in total).

\subsection{Between species comparison}

Table 5 presents behavioral categories registered in each species: Trinomys setosus and Clyomys laticeps. T. setosus was clearly more affiliative ( $78.6 \%$ of the affiliative and $21.3 \%$ of

Table 5. Occurrences of affiliative and agonistic behaviors in T. yonenagae (based on the literature), Trinomys setosus and Clyomys bishopi (in this study).

\begin{tabular}{|c|c|c|c|c|}
\hline \multirow[b]{2}{*}{ Categories } & \multirow[b]{2}{*}{ Social behaviour } & \multicolumn{2}{|c|}{ Occurrences } & \multirow[b]{2}{*}{ C. bishopi } \\
\hline & & T. yonenagae & T. setosus & \\
\hline \multirow{9}{*}{ Agonistic } & Advance & $\checkmark$ & $\checkmark$ & $\checkmark$ \\
\hline & Attack & $\checkmark$ & $\checkmark$ & $\checkmark$ \\
\hline & Bite & $\checkmark$ & $\checkmark$ & $\checkmark$ \\
\hline & Chase & $\checkmark$ & $\checkmark$ & $\checkmark$ \\
\hline & Face the other & $\mathrm{X}$ & $\checkmark$ & $\checkmark$ \\
\hline & Grab from behind & $\checkmark$ & $\checkmark$ & $\checkmark$ \\
\hline & Hit & $\mathrm{X}$ & $\checkmark$ & $\checkmark$ \\
\hline & Kick with a single foot & $\mathrm{X}^{*}$ & $\mathrm{X}$ & Not observed \\
\hline & Run away (turn away vigorously) & $\checkmark$ & $\checkmark$ & $\checkmark$ \\
\hline \multirow{13}{*}{ Affiliative } & Allogrooming & $\checkmark$ & $\checkmark$ & $\checkmark$ \\
\hline & Approach & $\checkmark$ & $\checkmark$ & $\checkmark$ \\
\hline & Body contact & $\checkmark$ & $\checkmark$ & $\checkmark$ \\
\hline & Mount (reproductive) & $\checkmark$ & $\checkmark$ & $\checkmark$ \\
\hline & Naso (rostrum)-anal contact & $\checkmark$ & $\checkmark$ & $\checkmark$ \\
\hline & Naso (rostrum)-auricular contact & $\checkmark$ & $\checkmark$ & $\checkmark$ \\
\hline & Naso (rostrum)-tail contact & $\sqrt{ }^{* *}$ & $\checkmark$ & $\checkmark$ \\
\hline & Naso (rostrum)-body contact & $\checkmark$ & $\checkmark$ & $\checkmark$ \\
\hline & Naso (rostrum)-nasal contact & $\checkmark$ & $\checkmark$ & $\checkmark$ \\
\hline & Naso (rostrum)-lumbar contact & $\checkmark$ & $\checkmark$ & $\checkmark$ \\
\hline & Stop in contact & $\checkmark$ & $\checkmark$ & $\checkmark$ \\
\hline & Touch with forefeet & $\checkmark$ & $\checkmark$ & Not observed \\
\hline & Trembling & $\mathrm{X}$ & $\checkmark$ & Not observed \\
\hline
\end{tabular}

$\checkmark=$ occurs in indicated species; $\mathbf{X}=$ not occurs, according to references and results of this study; not observed = not cited in consulted references; ? = no one knows the context involved to classified in which type (agonistic, affiliative, reproductive and others). ${ }^{* *}$ possibly the rostrum- tail contact observed by Alves in Freitas et al., 2008 *it is not clear whether the behaviour is present in Trinomys yonenagae, since the authors offer the ethogram from observations of 4 species: T. yonenagae, T. iheringi denigratus, T. albispinus minor and Thrichomys apereoides. In Saldanha-Filho (2008) the clade that includes T. denigratus and T. yonenagae is cited as having lost the agonistic behaviours of kick with a single foot and face the other. ${ }^{* *}$ possibly the rostrum- tail contact observed by Alves in Freitas et al., 2008. 
the agonistic) than Clyomys (55\% of the affiliative and $45 \%$ of the agonistic). Based on our sampling strategy, the behavioral repertoire of $T$. setosus is almost the same as that of $T$. yonenagae. Also, the differences between them and C. laticeps are not many: Clyomys lacks the affiliates touch with forefeet and foot-trembling that we saw in T. setosus. The huddling behavior in the light phase was observed in both species but relatively more frequently in $T$. setosus (occurred in $97 \%$ of the observations) than C. laticeps (30\% of the observations). Reproductive behavior (mount) was observed in both species, although only $T$. setosus reproduced in captivity.

\section{Discussion}

The two species we studied adopt a social life (sensu Lee, 1994). Trinomys setosus has a higher level of sociality than Clyomys, according to their relative tolerance to conspecifics of both sexes and the group cohesion (Lacher, 1981; Schwarz-Weig and Sachser, 1996; Adrian and Sachser, 2011). Aggressions in T. setosus were directed to newborns and juveniles and less commonly recorded among adults; in Clyomys, aggressions were mostly from females to males but also occurred between females.

We suggest that $T$. setosus has a level 4 or 5 of Lee's sociality scale. That means a social species with kinship, individual recognition, and social regulation rules (Lee, 1994). This elevated sociality level was observed in T. yonenagae (Freitas et al., 2008; 2010). As described to that species, when established in captivity enclosures, conflicts would cease days after group establishment and would be directed to one individual that, once removed, ends the aggression (Manaf and Spinelli Oliveira, 2000). This individual could be Charlie in our study. He was born in TG1-0 and started escaping successively, and once his sister, outside their enclosure (a month later, their mother delivered a new litter). The successive escapes finally stopped when we changed Charlie to the neighbor group. Tom also escaped from its group. More severe aggressions occurred in Clyomys, which showed no ability to jump or climb. As males were the sex that more frequently escaped or was hurt, we suggest a skewed male dispersion in both species forcing young males to leave their natal territory (Greenwood, 1980).

Females occupy a central role in the social network on T. setosus (L.M.R. Cantano pers. observation). Despite the apparent tolerance among Trinomys females, only one produced litter per time (and none in Clyomys): Fanny in TG2-0; Meg, after Fanny's death, in TG1; and Tina after six months without Meg's presence in the group (Cantano, 2018). We considered the hypothesis of reproductive dominance in this species but could not investigate it properly. Meg was a central individual in the social network, presenting the highest association indexes and strength values, and also formed a social dominance pair with Johnny (Cantano, 2018). This dominance could be physiological or behavioral, but once a dominant female had been removed from the group, another female emerged occupying the reproductive post (Meg after Fanny and Tina after Meg). The reproductive dominance strategy would not be a total novelty in caviomorphs, like this one among $T$. setosus females in captivity and on the free-living population of T. iheringi, but among males (Bergallo, 1995).
A reproductive succession line was also observed in the eusocial Heterocephalus glaber, an African Hystricognathi species, in captivity (Clarke and Faulkes, 1997).

Nevertheless, alternative explanations should be considered. Tina and Meg had almost the same body mass in the intervals when Meg was not heavier by the pregnancy. A difference in body mass or nutritional conditions (that could derive from its social status) could favor Meg but not Tina to get pregnant or to keep the fetus until its birth (Clutton-Brock, 1988; Festa Bianchet et al., 1998; Sapolsky, 2005; Blomquist and Turnquist, 2011). However, high dominance rank may confer other benefits, as suggested by Wright et al. (2020). Improving mate choice, lowering predation risk, and living under reduced social stress could favor litter production in higher status females, even when the dominance is light, as in gorillas' societies. These alternative explanations to Meg's reproductive behavior should be tested in future research.

\subsection{The affiliative repertoire of behaviors}

Trinomys setosus also has a complex repertoire of contact, promoting behaviors that contrast to the limited aggressive one, again resembling $T$. yonenagae (Manaf and Spinelli Oliveira, 2000); most agonistic interactions did not even escalate to fight. Males were tolerant to conspecifics and actively interacted with the youngers in a non-aggressive way, resting and foraging together, like T. yonenagae (Freitas et al., 2008; Manaf and Spinelli Oliveira, 2000). Meg and Johnny, the dominant animals, performed and received more allogrooming than the other adults. Most of the allogrooming received by Meg came from her infants, and Johnny groomed them (his infants; L.M.R. Cantano and collaborators pers. comm.) more than groomed any other individual. Allogrooming rate is frequently positively correlated to dominance and kinship in primates and some ungulates (Schino et al., 1988; Dunbar, 1991; Mooring et al., 2004). Our results show that it may also be the case in $T$. setosus.

Clyomus laticeps females were quantitatively more aggressive to males than $T$. setosus females. They were never found sleeping together. Allogrooming occurred only in half of the groups, once in CG2 and five in CG4. In CG3, females exhibited a higher frequency and more diversified agonistic than affiliative behaviors, except for F4 that was mostly affiliative and less attacked. In Lee's definition of sociality (1994), C. laticeps may be a level 2 (gregarious for most activities).

Resting together was frequent in T. setosus, except for one female (Meg), which was seen alone most of the time. Also, in Clyomys, there was one female that was always resting alone. In other caviomorphs, resting together could be a cooperative behavior for term regulation (Gilbert et al., 2010). It was described in intersexual tolerant species, as T. yonenagae (Manaf and Spinelli Oliveira, 2000; Manaf et al., 2003), Galea musteloides (Schwarz-Weig and Sachser, 1996), Cavia porcellus (Epplen et al., 1999), Microcavia australis (Taraborelli and Moreno, 2009), Octodon degus (Ebensperger et al., 2004), and Ctenomys sociabilis (Lacey et al., 1997; Lacey, 2004). It may be a conserved behavioral pattern of an ancient heritage in this rodent group's evolutionary history. 


\subsection{Reproductive behavior}

Despite the inter-sex social intolerance, we could keep a male with a female in three out of the four groups of Clyomys (CG1, CG2, and CG4). Females may accept a male into their enclosure when he shows attributes to mate choice or other intrinsic characteristics. We had two males, and we could insert one in each of those groups, but none was admitted in CG3. Among them, only one was accepted since its introduction. No significant sexual dimorphism was found in the genus Clyomys (Bezerra and Oliveira 2010), which could explain the females' apparent dominance and argue a monogamy hypothesis, as seen in Galea monasteriensis (Hohoff et al., 2002). When we excavated free-living populations' burrow systems, we found only one individual inhabiting each system (Luchesi, 2019). The social environment of a Clyomys female seems to be a colony of dozens of independent underground burrow systems, where she interacts over the ground with familiar animals of the colony (Bezerra et al., 2016). However, it goes back alone to her defended burrow system, maybe tolerating her daughters.

We had no time to find out Clyomys reproductive and parental behavior before losing access to the animals in LECO. Mounting occurred in July and August. However, the wet season was pointed to as the seasonal occurrence of reproduction in free-living populations of Clyomys, from December to April (Bishop, 1974). However, infants were seen in the dry season, from April to September (Vieira, 1997; Ferrando and Leiner, 2018). Nevertheless, in laboratory conditions, the animals' room humidity and temperature were almost constant.

In Trinomys, we saw a male mounting over another male (Peter mounted Zac 8 times), which could be interpreted as a dominance exhibition or strength demonstration (Rood, 1972). He also mounted both Amy and Fanny in the formation of the TG2-0. No sexual display was recorded. This absence could be a limitation in our sampling method once this behavior occurs at low rates and could be better observed using behavior sampling or continuous recordings. Nevertheless, it was described for T. yonenagae in intersexual pairing encounters: sexually aroused males hit the floor using the front feet (Manaf and Spinelli Oliveira, 2000). A front foot alternated tapping was observed in other caviomorphs, named stamping (Smythe, 1970; Eisenberg, 1974; Wilson and Kleiman, 1974). A whimper call is uttered with stamping during the courtship in Dinomys, Erethizon, and Myoprocta (Eisenberg, 1974).

\subsection{Warning or courting?}

For $T$. setosus, we described a trembling and a foot drumming accompanied by a trilled call. In T. yonenagae, the vocalization that may follow trembling is a trill-like call that is not always simultaneous to the hind feet movements. We did not register the drumming in C. laticeps. However, its sandy habitat would favor the seismic signal transmission and may be better than the habitat of $T$. setosus, a humid forest floor. Foot-drumming had been interpreted as a warning response in woodrats Neotoma albigula albigula (Vorhies and Taylor, 1940) and Mongolian gerbils Meriones unguiculatus (Ballard et al., 2001; Varty et al., 2002). In T. yonenagae, animals use to knock the hind feet 3 to 4 times on the floor, supposedly as an anti-predator warning with a role in individual recognition and to avoid predation (Manaf and Spinelli Oliveira, 2000).

The trembling variation of the foot-drumming resembles for its rhythmicity the courtship displays that Kleiman (1974) described for other caviomorph rodents (genera Agouti, Cavia, Dasyprocta, Dinomys, Lagostomus, and Myoprocta). The author related the foot tapping (named trembling in T. yonenagae, Manaf, and Spinelli Oliveira, 2000) to reproduction. It was not the case in which we registered $T$. setosus trembling, but it may be the behavior that could have been modified and ritualized to form the rumba of Cavia (Monticelli and Ades, 2011; Verzola-Olivio and Monticelli, 2017; VerzolaOlivio et al., 2021). In the T. setosus, the body movement was not laterally oriented but dorso-ventrally, more like the foot-drumming of Kerodon rupestris and Galea spixii (Alencar and Monticelli, 2021, in prep.). Similar topologies of drumming behavior are used in territorial defense or sexual interaction in the Cape mole-rat Georychus capensis (simultaneous striking of both hind feet against burrow ground with female replying; Bennett and Jarvis, 1988). For Meriones species, drumming was cited as a territorial signalization and a reproduction role (Bridelance and Paillette, 1985).

Trinomys setosus also produces foot drumming, as we described in aversive situations. That is also the context of the foot drumming in bushveld gerbil Tatera leucogaster produced with both hindfeet alternately hitting the ground (Dempster and Perrin, 1994). An ultrasonic whistle is uttered with some foot drumming knocks, according to the authors. The vocalization, a trilled whine or whimper, is repeated as long as the foot movement lasts and resembles the chirrup or song of Cavia species, used under disturbance in social or physical environments (Monticelli and Ades, 2013; Verzola-Olivio and Monticelli, 2017). Also, in the gerbil, Rhombomys opimus hitting the floor is accompanied by a whistle (Randall, 2010).

Seismic communication could be an adaptive strategy for predator risk detection in nocturnal rodents, like $T$. setosus and C. laticeps. Alternatively, it may have evolved as a means of communicating to predators (Shelley and Blumstein, 2005). The primordial role of drumming on the floor could be long-distance communication (seismic), whether for sexual or warning purposes. Vocal signals originated first than seismic signals, and the use of the sound produced by the shock of the foot on the ground as a communication signal could have emerged from the digging process (Francescoli and Altuna, 1998), eventually independently in phylogenetically unrelated rodent lineages (Schleich and Francescoli, 2018). Both species showed a relative conspecific tolerance, considering time or frequency of affiliative behaviors. It occurred at least $22.5 \%$ of the time in phase $1,74 \%$ in phase 2 , and $47 \%$ in Clyomys groups, and occurred since the individuals' first presentation in T. setosus. 


\subsection{Digging and catching food}

We saw T. setosus caching seeds buried in the ground but not digging to build burrows, although it presents the behavior of digging in captivity (Fabio-Braga and Klein, 2018). That could be related to its small rodent terrestrial habit that may also favor the forest's germinative process (Pinto et al., 2009) and serve them back with food. This behavior is performed using front legs against the substrate, filled with food using the snout. Something similar is observed in T. yonenagae (Manaf and Spinelli Oliveira, 2000). Unlike T. setosus, Clyomys collected and stored in individuals' nests almost all the food pellets offered. A female used to collect and carry a portion of pellets into one of the two wooden houses and repeal the male whenever he approached that nest. In CG1, a female's nest was frequently seen full of pellets, while the males had none, and once she was seen removing pellets from inside his nest.

Caching was observed in other terrestrial rodent species Leopoldamys sabanus, Maxomys spp., and Lariscus insignis and other rodent species (Forget, 1996; Yasuda et al., 2000). We did not register $C$. laticeps digging and hiding food but found cached food inside the shelters we provided. Studies with free-living populations cite burrows filled with stored food items (Lamberto and Leiner, 2019; Luchesi, 2019). Food hoarding strategy seems to be conservated in the three environments among echiymid species (tropical forest, Cerrado, and Caatinga). Food caching could be evolved as an adaptation to food availability in tropical rainforests (Smith and Reichman, 1984), optimizing foraging processes and environmental conservation (Smith and Reichman, 1984; Pinto et al., 2009). Both forms have an essential role in seed dispersal, with rodents acting as essential agents of secondary seed dispersal and seedling in Neotropical forests (Forget and Vander Wall, 2001) and savannah (Almeida and Galetti, 2007). Moreover, digging behavior could represent a behavioral lability response to life in Caatinga for T. yonenagae (Manaf and Spinelli Oliveira, 2000) and C. laticeps. The underground had offered the advantages of thermal comfort and protection against predators (Nevo, 1979; Stein, 2000; Ebensperger and Blumstein, 2006; Santos and Lacey, 2011) when the environment changed from humid forest to the semiarid (Vivo, 1997).

The behavioral repertoires described here enrich the knowledge about Trinomys setosus behavior and offer the first whole systematized ethogram for Clyomys. It is not surprising that the behavioral repertoires of $T$. setosus and $C$. laticeps were similar, even inhabiting different biomes (Atlantic Forest and Cerrado). Except for the touch with forefeet and other social contacts (naso-tail, naso-auricular, naso-lumbar, and stop in contact), the hit and the foot trembling, these species share their behavior patterns. That is, their behavior has similar topography and can be called using the same classifiers. T. yonenagae, while adjusting to life on the semiarid, has conserved its behavioral repertoire in relation to $T$. setosus, a forested species, and improved its digging ability, but not its social tolerance. The maintenance of repertoires among species of the same genus was seen in Cavia. Three wild species, one of them evolved in isolation in an island, and a domesticated one shared an extensive repertoire (Rood, 1972; Monticelli and Ades, 2013; Verzola-Olivio and Monticelli, 2017). Thus, part of cavies' behaviors is also present in the echimyd species we studied. The ethologists Eisenberg and Kleiman (1983) compared the behavioral displays of rodents and other mammals in an evolutive approach. They noticed that even among taxonomic families, the topography and constitution of the repertoires are preserved; changes are essentially in frequencies of exhibition or response threshold (Kleiman and Eisenberg, 1973; Wilson and Kleiman, 1974; Eisenberg and Kleiman, 1977, 1983; Kleiman, 2011).

The contribution of our descriptive study of behavioral repertoires, as we hope, is to yield primary data, with standardizing terms and categories, that can be used in behavioral research (Masatomi, 2004; Baker et al., 2017). We have studied the two echimyd species for the first time in social conditions, that is, observing animals living in groups. We hope it serves a better understanding of their social behavior and presents a more realistic scenario in comparison to T. yonenagae. Moreover, the studied species are potential indicators of environmental quality (Bonvicino et al., 2002). As they are also acoustic species (Takata et al., 2014), they can be monitored with automated bioacoustic systems (Blumstein et al., 2011; Monticelli et al., 2016) and foment decisions concerning biodiversity conservation, especially needed in Brazil.

\section{Final considerations}

We must consider here the effects of the captive environment on the animal's behavior. A restricted environment and eventual differences in the social composition of captive and free-living groups are factors of considerable importance in any captive study (McPhee, 2004; Kleiman et al., 2010). Nevertheless, they have practical applications to the zoos and commercial farms of wild animals (Eisenberg and Kleiman, 1977; Kleiman, 1980). Besides, T. yonenagae and Cavia aperea populations long-term maintenance in the laboratory had no significant impact on the expression of behavior nor in physiological parameters (Künzl et al., 2003; Fabio Braga and Klein 2018), and captivity may be the only way to study nocturnal species.

There are restrictive issues for observing free-living mammals that, for decades, have been outlined with careful studies of free-living animals captured in the wild (or rescued) and established in animal facilities in universities or zoos (Kleiman, 1974; Kleiman et al., 1979). Devra Kleiman and John Eisenberg promoted a massive part of the knowledge we have about behavioral repertoires in comparative perspectives, in captivity. Other conditions could improve knowledge about sociality among spinyrats. There is not yet the technology that can outline the tameness and the nocturnal habits of forest rodents that permit ethological studies of behavior. Robots or drones will soon improve our observing capabilities of free-living species of mammals (Schroeder et al., 2020). Until they get more accessible, captivity is still the most prone resource for detailed descriptions like this one. 


\section{Acknowledgements}

Authors would like to thank the Ph. D. Jorge Nei Freitas and Professor Elisabeth Spinelli de Oliveira that provided and helped us obtain information and access to the animals (Clyomys at LECO and Trinomys in ours EBAC). We also thank B. Sc. Thalita A.R.P. Gonçalves for advice and technical assistance. This research was supported by Coordenação de Aperfeiçoamento de Pessoal de Nível Superior (CAPES), FAPESP (11/18253-7), and University of São Paulo (PIBIC grant).

\section{References}

ADRIAN, O. and SACHSER, N., 2011. Diversity of social and mating systems in cavies: a review. Journal of Mammalogy, vol. 92, no. 1, pp. 39-53. http://dx.doi.org/10.1644/09-MAMM-S-405.1.

ALENCAR, J.R. and MONTICELLI, P.F., 2021. The description of the acoustic communication system of Kerodon rupestris with a discussion about its taxonomic position. Behavioural Processes. In press.

ALMEIDA, L.B. and GALETTI, M., 2007. Seed dispersal and spatial distribution of Attalea geraensis (Arecaceae) in two remnants of Cerrado in southeastern Brazil. Acta Oecologica, vol. 32, no. 2, pp. 180-187. http://dx.doi.org/10.1016/j.actao.2007.04.001.

ALTMANN, J., 1974. Observational study of behavior: sampling methods. Behaviour, vol. 49, no. 3-4, pp. 227-266. http://dx.doi. org/10.1163/156853974X00534. PMid:4597405.

BALLARD, T.M., SANGER, S. and HIGGINS, G.A., 2001. Inhibition of shock-induced foot tapping behaviour in the gerbil by a tachykinin NK(1) receptor antagonist. European Journal of Pharmacology, vol. 412, no. 3, pp. 255-264. http://dx.doi. org/10.1016/S0014-2999(01)00724-5. PMid:11166289.

BAKER, K.C., BLOOMSMITH, M.A., COLEMAN, K., CROCKETT, C.M., WORLEIN, J., LUTZ, C.K., MCCOWAN, B., PIERRE, P. and WEED, J., 2017. The Behavioral Management Consortium: a partnership for promoting consensus and best practices. In: S.J. SCHAPIRO, ed. Handbook of primate behavioral management. CRC Press, pp. 9-24. http://dx.doi.org/10.1201/9781315120652-2.

BENNETT, N.C. and JARVIS, J.U.M., 1988. The reproductive biology of the Cape mole-rat, Georychus capensis (Rodentia, Bathyergidae). Journal of Zoology, vol. 214, no. 1, pp. 95-106. http://dx.doi. org/10.1111/j.1469-7998.1988.tb04989.x.

BERGALLO, H.G., 1995. Comparative life history characteristics of two species of rats, Proechimys iheringi and Oryzomys intermedius, in an Atlantic Forest of Brazil. Mammalia, vol. 59, no. 1, pp. 51-64. http://dx.doi.org/10.1515/mamm.1995.59.1.51.

BEZERRA, A.M.R. and OLIVEIRA, J.A., 2010. Taxonomic implications of cranial morphometric variation in the genus Clyomys Thomas, 1916 (Rodentia: echimyidae). Journal of Mammalogy, vol. 91, no. 1, pp. 260-272. http://dx.doi.org/10.1644/08-MAMM-A-320R1.1.

BEZERRA, A.M.R., OLIVEIRA, J.A. and BONVICINO, C.R., 2016. Clyomys laticeps (Rodentia: echimyidae). Mammalian Species, vol. 48, no. 938, pp. 83-90. http://dx.doi.org/10.1093/mspecies/sew009.

BISHOP, I.R., 1974. An annotated list of caviomorph rodents collected in North-eastern Mato Grosso Brazil. Mammalia, vol. 38, no. 3 , pp. 489-502. http://dx.doi.org/10.1515/mamm.1974.38.3.489.

BLOMQUIST, G.E. and TURNQUIST, J.E., 2011. Selection on adult female body size in rhesus macaques. Journal of Human Evolution, vol. 60, no. 6, pp. 677-683. http://dx.doi.org/10.1016/j. jhevol.2010.05.010. PMid:21463885.
BLUMSTEIN, D.T., MENNILL, D.J., CLEMINS, P., GIROD, L., YAO, K., PATRICELLI, G., DEPPE, J.L., KRAKAUER, A.H., CLARK, C., CORTOPASSI, K.A., HANSER, S.F., MCCOWAN, B., ALI, A.M. and KIRSCHEL, A.N.G, 2011. Acoustic monitoring in terrestrial environments using microphone arrays: applications, technological considerations and prospectus. Journal of Applied Ecology, vol. 48, no. 3, pp. 758-767. http://dx.doi. org/10.1111/j.1365-2664.2011.01993.x.

BONVICINO, C.R., LINDBERGH, S.M. and MAROJA, L.S., 2002. Small non-flying mammals from conserved and altered areas of Atlantic Forest and Cerrado: comments on their potencial use for monitoring environment. Brazilian Journal of Biology $=$ Revista Brasileira de Biologia, vol. 62, no. 4B, pp. 765-774. http://dx.doi. org/10.1590/S1519-69842002000500005. PMid:12659027.

BRIEFER, E.F., TETTAMANTI, F. and MCELLIGOTT, A.G., 2015. Emotions in goats: mapping physiological, behavioural and vocal profiles. Animal Behaviour, vol. 99, pp. 131-143. http:// dx.doi.org/10.1016/j.anbehav.2014.11.002.

BRIDELANCE, P. and PAILLETTE, M., 1985. Un système original de communication sonore chez des rongeurs désertiques: La podophonic chez quatre espèces de Meriones (Rongeurs, Gerbillides). Mammalia, vol. 49, no. 2, pp. 161-172. http://dx.doi. org/10.1515/mamm.1985.49.2.161.

BURKHARDT, R.W., 2005. Patterns of behavior: Konrad Lorenz, Niko Tinbergen, and the founding of ethology. Chicago, Illinois: University of Chicago Press. 496p.

CAMERON, L.P., BENSON, C.J., DUNLAP, L.E. and OLSON, D.E., 2018. Effects of $N, N$ Dimethyltryptamine on rat behaviors relevant to anxiety and depression. ACS Chemical Neuroscience, vol. 9, no. 7, pp. 1582-1590. http://dx.doi.org/10.1021/ acschemneuro.8b00134. PMid:29664276.

CANTANO, L.M.R., 2018. Comportamento e dinâmica social de duas espécies de ratos-de espinho em cativeiro sob a visão das redes sociais. Ribeirão Preto: Universidade de São Paulo, 219 p. Tese de Doutorado em Ciências- Psicobiologia.

CLARKE, F.M. and FAULKES, C.G., 1997. Dominance and queen succession in captive colonies of the eusocial naked mole-rat, Heterocephalus glaber. Proceedings. Biological Sciences, vol. 264, no. 1384, pp. 993-1000. http://dx.doi.org/10.1098/rspb.1997.0137. PMid:9263466.

CLUTTON-BROCK, T.H., 1988. Reproductive success: studies of individual variation in contrasting breeding systems. Chicago: University of Chicago Press, 538p.

DEMPSTER, E.R. and PERRIN, M.R., 1994. Divergence in acoustic repertoire of sympatric and allopatric gerbil species (Rodentia: gerbillinae). Mammalia, vol. 58, no. 1, pp. 93-104. http://dx.doi. org/10.1515/mamm.1994.58.1.93.

DONATTI, A.F. and LEITE-PANISSI, C.R.A., 2011. Activation of corticotropin-releasing factor receptors from the basolateral or central amygdala increases the tonic immobility response in guinea pigs: an innate fear behavior. Behavioural Brain Research, vol. 225, no. 1, pp. 23-30. http://dx.doi.org/10.1016/j. bbr.2011.06.027. PMid:21741994.

DORPH, A. and MCDONALD, P.G., 2017. The acoustic repertoire and behavioural context of the vocalizations of a nocturnal dasyurid, the eastern quoll (Dasyurus viverrinus). PLoS One, vol. 12, no. 7, pp. e0179337. http://dx.doi.org/10.1371/journal. pone.0179337. PMid:28686679.

DUNBAR, R.I.M., 1991. Functional significance of social grooming in Primates. Folia Primatologica, vol. 57, no. 3, pp. 121-131. http:// dx.doi.org/10.1159/000156574.

EBENSPERGER, L.A. and BLUMSTEIN, D.T., 2006. Sociality in New World hystricognath rodents is linked to predators and burrow 
digging. Behavioral Ecology, vol. 17, no. 3, pp. 410-418. http:// dx.doi.org/10.1093/beheco/arj048.

EBENSPERGER, L.A., HURTADO, M.J., SOTO-GAMBOA, M., LACEY, E.A. and CHANG, A.T., 2004. Communal nesting and kinship in degus (Octodon degus). Naturwissenschaften, vol. 91, no. 8, pp. 391-395. http://dx.doi.org/10.1007/s00114-004-0545-5. PMid:15309311.

EISENBERG, J.F., 1974. The function and motivational basis of hystricomorph vocalizations. Symposia of the Zoological Society of London, no. 34, pp. 211-244.

EISENBERG, J.F. and KLEIMAN, D.G. 1983. Advances in the study of mammalian behavior. Shippensburg, US: American Society of Mammalogists, 753 p., Special publication (American Society of Mammalogists), no. 7.

EISENBERG, J. and KLEIMAN, D.G., 1977. The usefulness of behaviour studies in developing captive breeding programmes for mammals. International Zoo Yearbook, vol. 17, no. 1, pp. 81-89. http://dx.doi.org/10.1111/j.1748-1090.1977.tb00871.x.

EPPLEN, J., SCHWARZ-WEIG, E., KEIL, A. and SACHSER, N., 1999. Behavioural strategies, testis size, and reproductive success in two caviomorph rodents with different mating systems. Behaviour, vol. 136, no. 9, pp. 1203-1217. http://dx.doi. org/10.1163/156853999501720.

FABIO-BRAGA, A.P. and KLEIN, W., 2018. Temperature and circadian effects on metabolic rate of South American Echimyid rodents, Trinomys setosus and Clyomys bishop (Rodentia: echimyidae). Zoologia, vol. 35, pp. 1-6. http://dx.doi.org/10.3897/zoologia.35. e24572.

FABRE, P.H., UPHAM, N.S., EMMONS, L.H., JUSTY, F., LEITE, Y.L., LOSS, A.C., ORLANDO, L., TILAK, M.K., PATTERSON, B.D. and DOUZERY, E.J., 2016. Mitogenomic phylogeny, diversification, and biogeography of South American spiny rats. Molecular Biology and Evolution, vol. 34, no. 3, pp. 613-633. http://dx.doi. org/10.1093/molbev/msw261. PMid:28025278.

FABRE, P.H., GALEWSKI, T., TILAK, M. and DOUZERY, E.J.P., 2013. Diversification of South American spiny rats (Echimyidae): a multigene phylogenetic approach. Zoologica Scripta, vol. 42, no. 2 , pp. 117-134. http://dx.doi.org/10.1111/j.1463-6409.2012.00572.x.

FERRANDO, C.P.R. and LEINER, N.O., 2018. Above-ground activity patterns of the semi fossorial spiny rat Clyomys laticeps. Ethology Ecology and Evolution, vol. 30, no. 4, pp. 373-383. http://dx.doi. org/10.1080/03949370.2017.1371247.

FESTA-BIANCHET, M., GAILLARD, J.M. and JORGENSON, J.T., 1998. Mass-and density dependent reproductive success and reproductive costs in a capital breeder. American Naturalist, vol. 152, no. 3, pp. 367-379. http://dx.doi.org/10.1086/286175. PMid: 18811445 .

FONSECA, G.A.B. and KIERULFF, M.C.M., 1989. Biology and natural history of Brazilian Atlantic Forest small mammals. Bulletin Florida State Museum, vol. 34, no. 3, pp. 99-152.

FORGET, P.M., 1996. Removal of seeds of Carapa procera (Meliaceae) by rodents and their fate in rainforest in French Guiana. Journal of Tropical Ecology, vol. 12, no. 6, pp. 751-761. http://dx.doi. org/10.1017/S0266467400009998.

FORGET, P.-M. and VANDER WALL, S.B., 2001. Scatter-hoarding rodents and marsupials: convergent evolution on diverging continents. Trends in Ecology \& Evolution, vol. 16, no. 2, pp. 65-67. http://dx.doi.org/10.1016/S0169-5347(00)02072-3. PMid:11165699.

FRANCESCOLI, G. and ALTUNA, C.A., 1998. Vibrational communication in subterranean rodents: the possible origin of different strategies. Evolution of Communication, vol. 2, no. 2, pp. 217 231. http://dx.doi.org/10.1075/eoc.2.2.04fra.
FREITAS, J.N.S., SILVA CARVALHO, L.A., EL-HANI, C.N. and DA ROCHA, P.L.B., 2010. Affiliation in the social interactions in captivity of the torch tail rat, Trinomys yonenagae (Rodentia: echimyidae). Journal of Ethology, vol. 28, no. 1, pp. 105-112. http://dx.doi. org/10.1007/s10164-009-0161-0.

FREITAS, J.N.S., EL-HANI, C.N. and DA ROCHA, P.L.B., 2008. Affiliation in four echimyid rodent species based on intrasexual dyadic encounters: evolutionary implications. Ethology, vol. 114, no. 4, pp. 389-397. http://dx.doi.org/10.1111/j.1439-0310.2008.01481.x.

GALEWSKI, T., MAUFFREY, J.F., LEITE, Y.L., PATTON, J.L. and DOUZERY, E.J., 2005. Ecomorphological diversification among South American spiny rats (Rodentia; Echimyidae): a phylogenetic and chronological approach. Molecular Phylogenetics and Evolution, vol.34, no. 3, pp. 601-615. http://dx.doi.org/10.1016/j. ympev.2004.11.015. PMid:15683932.

GILBERT, C., MCCAFFERTY, D., LE MAHO, Y., MARTRETTE, J.M., GIROUD, S., BLANC, S. and ANCEL, A., 2010. One for all and all for one: the energetic benefits of huddling in endotherms. Biological Reviews of the Cambridge Philosophical Society, vol. 85, no. 3, pp. 545-569. http://dx.doi.org/10.1111/j.1469-185X.2009.00115.x. PMid:20039866.

GRANT, S.G. 2016. The molecular evolution of the vertebrate behavioural repertoire. Philosophical Transactions of the Royal Society B: Biological Sciences, vol. 371, no. 1685, pp. 20150051. https://doi.org/10.1098/rstb.2015.0051.

GREENWOOD, P.J., 1980. Mating systems, philopatry and dispersal in birds and mammals. Animal Behaviour, vol. 28, no. 4, pp. 1140-1162. http://dx.doi.org/10.1016/S0003-3472(80)80103-5.

HOHOFF, C., SOLMSDORFF, K., LÖTTKER, P., KEMME, K., EPPLEN, J., COOPER, T. and SACHSER, N., 2002. Monogamy in a new species of wild guinea pigs (Galea sp.). Naturwissenschaften, vol. 89, no. 10, pp. 462-465. http://dx.doi.org/10.1007/s00114002-0355-6. PMid:12384721.

KLEIMAN, D.G., 2011. Canid mating systems, social behavior, parental care and ontogeny: are they flexible? Behavior Genetics, vol. 41, no. 6, pp. 803-809. http://dx.doi.org/10.1007/s10519-0119459-0. PMid:21487689.

KLEIMAN, D.G., 1980. The sociobiology of captive propagation. In: WILCOX, B. and SOULE, M. ed. Conservation biology: An evolutionary-ecological perspective. Suderland: Sinauer Associates, pp. 243-261.

KLEIMAN, D.G., 1974. Patterns of behavior in hystricomorph rodents. Symposia of the Zoological Society of London, vol. 34, pp. 171-209.

KLEIMAN, D.G. and EISENBERG, J.F., 1973. Comparisons of canid and felid social systems from an evolutionary perspective. Animal Behaviour, vol. 21, no. 4, pp. 637-659. http://dx.doi.org/10.1016/ S0003-3472(73)80088-0. PMid:4798194.

KLEIMAN, D.G., EISENBERG, J.F. and MALINIAK, E. 1979. Reproductive parameters and productivity of caviomorph rodents. In: EISENBERG, J.F. Vertebrate ecology in the northern neotropics. Washington: Smithsonian Institution, pp. 173-183.

KLEIMAN, D.G., THOMPSON, K.V. and BAER, C.K., 2010. Wild mammals in captivity: principles and techniques for zoo management. 2nd ed. Chicago: University of Chicago Press. 592 p. http://dx.doi. org/10.7208/chicago/9780226440118.001.0001.

KÜNZL, C., KAISER, S., MEIER, E. and SACHSER, N., 2003. Is a wild mammal kept and reared in captivity still a wild animal? Hormones and Behavior, vol. 43, no. 1, pp. 187-196. http:// dx.doi.org/10.1016/S0018-506X(02)00017-X. PMid:12614649.

LACHER, T.E., 1981. The comparative social behavior of Kerodon rupestris and Galea spixii and the evolution of behavior in the Caviidae. Bulletin of Carnegie Museum of Natural History., vol. 17, pp. 1-71. 
LACEY, E.A., 2004. Sociality reduces individual direct fitness in a communally breeding rodent, the colonial tuco-tuco (Ctenomys sociabilis). Behavioral Ecology and Sociobiology, vol. 56, no. 5, pp. 449-457. http://dx.doi.org/10.1007/s00265-004-0805-6.

LACEY, E.A., BRAUDE, S.H. and WIECZOREK, J.R., 1997. Burrow sharing by colonial tuco tucos (Ctenomys sociabilis). Journal of Mammalogy, vol. 78, no. 2, pp. 556-562. http://dx.doi. org/10.2307/1382907.

LAMBERTO, J. and LEINER, N.O., 2019. Broad-headed spiny rats (Clyomys laticeps) as ecosystem engineers in the Brazilian savannah. Journal of Zoology, vol. 309, no. 1, pp. 60-68. http:// dx.doi.org/10.1111/jzo.12684.

LEE, P.C. 1994. Social structure and evolution. In: P.J.B. SLATER, T.R. HALLIDAY and P. BARRETT. Behaviour and Evolution. New York, NY: Cambridge University Press, pp. 266-303.

LEHNER, P.N., 1996. Handbook of Ethological Methods. 2nd ed. Colorado, US: Colorado State University, 672 p.

LORENZ, K.Z., 1966. Evolution of ritualization in the biological and cultural spheres. Philosophical Transactions of the Royal Society of London. Series B, Biological Sciences, vol. 251, no. 772, pp. 273-284. http://dx.doi.org/10.1098/rstb.1966.0011.

LUCHESI, L.C., 2019. O espaço subterrâneo do rato-de-espinho Clyomys bishopi: caracterização e previsões possíveis sobre sua biologia comportamental. Ribeirão Preto: Universidade de São Paulo, 60 p. Tese de Doutorado em Ciências- Psicobiologia.

LUCHESI, L.C., CANTANO, L.M.R., TAKATA, J.T. and MONTICELLI, P.F., 2019. Trinomys yonenagae (Rodentia: echimyidae). Mammalian Species, vol. 51, no. 971, pp. 1-10. http://dx.doi.org/10.1093/ mspecies/sez001.

MANAF, P., MORATO, S. and SPINELLI OLIVEIRA, E., 2003. Profile of wild Neotropical spiny rats (Trinomys, Echimyidae) in two behavioral tests. Physiology \& Behavior, vol. 79, no. 2, pp. 129-133. http://dx.doi.org/10.1016/S0031-9384(03)00121-5. PMid:12834782.

MANAF, P. and SPINELLI OLIVEIRA, E., 2000. Behavioral Repertoire of the Spiny Rat Proechimys (Trinomys) yonenagae (Rodentia: Echimyidae) in captivity. Revista de Etologia, vol. 2, no. 1, pp. 3-15.

MARCOMINI, M. and OLIVEIRA, E.S., 2003. Activity pattern of Echimyid rodent species from the Brazilian Caatinga in captivity. Biological Rhythm Research, vol. 34, no. 2, pp. 157-166. http:// dx.doi.org/10.1076/brhm.34.2.157.14491.

MASATOMI, H., 2004. Individual (non-social) behavioral acts of hooded cranes Grus monacha wintering in Izumi. Japan Journal of Ethology, vol. 22, no. 1, pp. 69-83. http://dx.doi.org/10.1007/ s10164-003-0103-1.

MCPHEE, M.E., 2004. Generations in captivity increases behavioral variance: considerations for captive breeding and reintroduction programs. Biological Conservation, vol. 115, no. 1, pp. 71-77. http://dx.doi.org/10.1016/S0006-3207(03)00095-8.

MONTICELLI, P.F. and ADES, C., 2013. The rich acoustic repertoire of a precocious rodent, the wild cavy Cavia aperea. Bioacoustics, vol. 22, no. 1, pp. 49-66. http://dx.doi.org/10.1080/09524622 .2012.711516

MONTICELLI, P.F. and ADES, C., 2011. Bioacoustics of domestication: alarm and courtship calls of wild and domestic cavies. Bioacoustics, vol. 20, no. 2, pp. 169-191. http://dx.doi.org/10.1 080/09524622.2011.9753642.

MONTICELLI, P., PAULA, B.C., BALIEIRO, F. and FARIA, R.R.A., 2016. Um relato atual da prática da bioacústica de mamíferos terrestres no Brasil. In Anais do $14^{\circ}$ Congresso de Engenharia de Áudio da AES-Brasil, 17-19 maio 2016, São Paulo,SP. Rio de Janeiro: Sociedade de Engenharia de Áudio, pp. 90-95.
MOORING, M.S., BLUMSTEIN, D.T. and STONER, C.J., 2004. The evolution of parasite defense grooming in ungulates. Biological Journal of the Linnean Society. Linnean Society of London, vol. 81, no. 1, pp. 17-37. http://dx.doi.org/10.1111/j.10958312.2004.00273.x.

NEVO, E., 1979. Adaptive convergence and divergence of subterranean mammals. Annual Review of Ecology and Systematics, vol. 10, no. 1, pp. 269-308. http://dx.doi.org/10.1146/ annurev.es.10.110179.001413.

NORTON, W.H.J. and CARREÑO GUTIÉRREZ, H., 2019. The threespined stickleback as a model for behavioural neuroscience. PLoS One, vol. 14, no. 3, pp. e0213320. http://dx.doi.org/10.1371/ journal.pone.0213320. PMid:30913214.

PESSÔA, L.M., TAVARES, W.C., OLIVEIRA, J.A. and PATTON, J.L., 2015. Genus Trinomys Thomas, 1921. Mammals of South America, vol. 2, pp. 999-1019.

PINTO, S.R.R., SANTOS, A.M.M. and TABARELLI, M., 2009. Seed predation by rodents and safe sites for large-seeded trees in a fragment of the Brazilian Atlantic forest. Brazilian Journal of Biology = Revista Brasileira de Biologia, vol. 69, no. 3, pp. 763771. http://dx.doi.org/10.1590/S1519-69842009000400003. PMid: 19802435.

RANDALL, J.A. 2010. Drummers and stompers: vibrational communication in mammals. In: C. E. O'CONNELL-RODWELL, ed. The use of vibrations in communication: properties, mechanisms and function across taxa. Transworld, Kerala, pp. 99-120.

ROCHA, P.L.B., 1995. Proechimys yonenagae, a new species of spiny rat (Rodentia: Echimyidae) from fossil sand dunes in the Brazilian Caatinga. Mammalia, vol. 59, no. 4, pp. 537-550. http://dx.doi.org/10.1515/mamm.1995.59.4.537.

ROOD, J.P., 1972. Ecological and behavioural comparisons of three genera of Argentine cavies. Animal Behaviour Monographs, vol. 5, pp. 1-83. http://dx.doi.org/10.1016/S0066-1856(72)80002-5.

SALDANHA FILHO, A.J.M., 2008. Evolução dos Tipos de Comportamentos Sociais em Trinomys (Rodentia: Echimyidae). Salvador: Universidade Federal da Bahia, 73p. Mestrado em Ecologia e Biomonitoramento.

SANTOS, J.W.A. and LACEY, E.A., 2011. Burrow sharing in the desert-adapted torch-tail spiny rat, Trinomys yonenagae. Journal of Mammalogy, vol. 92, no. 1, pp. 3-11. http://dx.doi. org/10.1644/09-MAMM-S-389.1.

SAPOLSKY, R.M., 2005. The influence of social hierarchy on primate health. Science, vol. 308, no. 5722, pp. 648-652. http://dx.doi. org/10.1126/science.1106477. PMid:15860617.

SCHINO, G., SCUCCHI, S., MAESTRIPIERI, D. and TURILLAZZI, P.G., 1988. Allogrooming as a tension-reduction mechanism: a behavioral approach. American Journal of Primatology, vol. 16, no. 1, pp. 43-50. http://dx.doi.org/10.1002/ajp.1350160106. PMid:31968881.

SCHLEICH, C. and FRANCESCOLI, G. 2018. Three decades of subterranean acoustic communication studies. In: M.L. DENT, R.R. FAY and A.N. POPPER, eds. Rodent Bioacoustics Rodent Bioacoustics. Cham: Springer, pp. 43-69. http://dx.doi. org/10.1007/978-3-319-92495-3_3.

SCHROEDER, N.M., PANEBIANCO, A., GONZALEZ MUSSO, R. and CARMANCHAHI, P., 2020. An experimental approach to evaluate the potential of drones in terrestrial mammal research: a gregarious ungulate as a study model. Royal Society Open Science, vol. 7, no. 1, pp. 191482. http://dx.doi.org/10.1098/ rsos.191482. PMid:32218965.

SCHWARZ-WEIG, E. and SACHSER, N., 1996. Social behaviour, mating system and testes size in cuis (Galea musteloides). Zeitschrift fur Saugetierkunde, vol. 61, no. 1, pp. 25-38. 
SHELLEY, E.L. and BLUMSTEIN, D.T., 2005. The evolution of vocal alarm communication in rodents. Behavioral Ecology, vol. 16, no. 1, pp. 169-177. http://dx.doi.org/10.1093/beheco/arh148.

SMITH, C.C. and REICHMAN, O.J., 1984. The evolution of food caching by birds and mammals. Annual Review of Ecology and Systematics, vol. 15, no. 1, pp. 329-351. http://dx.doi.org/10.1146/ annurev.es.15.110184.001553.

SMYTHE, N., 1970. On the existence of "pursuit invitation" signals in mammals. American Naturalist, vol. 104, no. 939, pp. 491-494. http://dx.doi.org/10.1086/282684.

STEIN, B.R., 2000. Morphology of subterranean rodents. In: E.A. LACEY, J.L. PATTON and G.N. CAMERON, eds. Life underground: the biology of subterranean rodents. Chicago, Illinois: University of Chicago Press, pp. 19-61.

TAKATA, J.T., MONTICELLI, P.F. and LUCHESI, L.C., 2014 [viewed 11 April 2019]. Social and acoustic behavior of the spiny-rat of forest, Trinomys setosus denigratus (Rodentia: Echimyidade): a comparison with the Caatinga species, Trinomys yonenagae. In: Proceedings of the 22nd International Symposium on Scientific Initiation of the University of São Paulo, September 2014, São Paulo. São Paulo: USP. Available from: siicusp.prp.usp.br/pt/ home/

TARABORELLI, P. and MORENO, P., 2009. Comparing composition of social groups, mating system and social behaviour in two populations of Microcavia australis. Mammalian Biology Zeitschrift für Säugetierkunde, vol. 74, no. 1, pp. 15-24. http:// dx.doi.org/10.1016/j.mambio.2008.08.002.

TAVARES, W.C., PESSÔA, L.M. and SEUÁNEZ, H.N., 2015. PlioPleistocene history of the endangered spiny rat Trinomys eliasi (Echimyidae) from Rio de Janeiro, Brazil. Journal of Mammalogy, vol. 96, no. 1, pp. 94-106. http://dx.doi.org/10.1093/jmammal/ gyu010.

TEN CATE, C., 2009. Niko Tinbergen and the red patch on the herring gull's beak. Animal Behaviour, vol. 77, no. 4, pp. 785-794. http:// dx.doi.org/10.1016/j.anbehav.2008.12.021.

THOMAS, O., 1916. Some notes on Echimyidae. Annals \& Magazine of Natural History, vol. 18, no. 105, pp. 194-303. http://dx.doi. org/10.1080/00222931608693851.
TINBERGEN, N., 1963. On aims and methods of Ethology. Zeitschrift für Tierpsychologie, vol. 20, no. 4, pp. 410-433. http://dx.doi. org/10.1111/j.1439-0310.1963.tb01161.x.

VARTY, G., COHEN-WILLIAMS, M., MORGAN, C., PYLAK, U., DUFFY, R., LACHOWICZ, J., CAREY, G. and COFFIN, V., 2002. The Gerbil Elevated Plus-maze II: Anxiolytic-like Effects of Selective Neurokinin NK1 Receptor Antagonists. Neuropsychopharmacol, vol. 27, no. 3, pp. 371-379. http://dx.doi.org/10.1016/S0893133X(02)00313-5. PMid:12225694.

VERZOLA-OLIVIO, P. and MONTICELLI, P.F., 2017. The acoustic repertoire of Cavia intermedia as a contribution to the understanding of the Caviidae communication system. Bioacoustics, vol. 26, no. 3, pp. 285-304. http://dx.doi.org/10.1 080/09524622.2016.1278401.

VERZOLA-OLIVIO, P., FERREIRA, B.L., FREI, F. and MONTICELLI, P.F., 2021. Guinea pig's courtship call: cues for identity and male dominance status? Animal Behaviour, vol. 174, pp. 237-247. http://dx.doi.org/10.1016/j.anbehav.2021.01.023.

VIEIRA, M.V., 1997. Dynamics of a rodent assemblage in a Cerrado of southeast Brazil. Revista Brasileira de Biologia, vol. 57, pp. 99-107.

VIVO, M.D., 1997. Mammalian evidence of historical ecological change in the Caatinga semiarid vegetation of northeastern Brazil. Journal of Computational Biology, vol. 2, pp. 65-73.

VORHIES, C.T. and TAYLOR, W.P., 1940. Life history and ecology of the white-throated woodrat, Neotoma albigula albigula Hartley, in relation to grazing in Arizona. Tucson, AZ: College of Agriculture, University of Arizona, 80 p. Technical Bulletin, no. 86.

WILSON, S.C. and KLEIMAN, D.G., 1974. Eliciting play: a comparative study: (Octodon, Octodontomys, Pediolagus, Phoca, Chocropsis, Ailuropoda). American Zoologist, vol. 14, no. 1, pp. 341-370.

WRIGHT, E., GALBANY, J., MCFARLIN, S.C., NDAYISHIMIYE, E., STOINSKI, T.S. and ROBBINS, M.M., 2020. Dominance rank but not body size influences female reproductive success in mountain gorillas. PLoS One, vol. 15, no. 6, pp. e0233235. http:// dx.doi.org/10.1371/journal.pone.0233235. PMid:32492071.

YASUDA, M., MIURA, S. and HUSSEIN, N.A., 2000. Evidence for food hoarding behaviour in terrestrial rodents in pasoh forest reserve, a malaysian lowland rain forest. Journal of Tropical Forest Science, vol. 12, no. 1, pp. 164-173. 


\section{Supplementary Material}

Supplementary material accompanies this paper.

Video S1 Foot-trembling behavior in captive Trinomys setosus individual. Recorded by Juliana Takata (2014).

Vídeo S2 Foot tapping behavior in captive Trinomys setosus individual. Recorded by Juliana Takata (2014)

Vídeo S3 Digging behavior in captive Trinomys setosus individual. Recorded by Juliana Takata (2014)

This material is available as part of the online article from http://www.scielo.br/bjb 